Article

\title{
A Simple and Effective Bioassay Method Suitable to Comparative In Vitro Study of Tomato Salt Tolerance at Early Development Stages
}

\author{
Marat R. Khaliluev ${ }^{1,2, *(\mathbb{D}) \text {, Liliya R. Bogoutdinova }}{ }^{3}$, Galina N. Raldugina ${ }^{4}$ and Ekaterina N. Baranova ${ }^{3,5}$ (D) \\ 1 Laboratory of Plant Cell Engineering, All-Russia Research Institute of Agricultural Biotechnology, \\ Timiryazevskaya 42, 127550 Moscow, Russia \\ 2 Department of Biotechnology, Institute of Agrobiotechnology, Russian State Agrarian University—Moscow \\ Timiryazev Agricultural Academy, Timiryazevskaya 49, 127550 Moscow, Russia \\ 3 Laboratory of Plant Cell Biology, All-Russia Research Institute of Agricultural Biotechnology, \\ Timiryazevskaya 42, 127550 Moscow, Russia; bogoutdinova_lr@rambler.ru (L.R.B.); \\ greenpro2007@rambler.ru (E.N.B.) \\ 4 Laboratory of Ion Transport and Salinity Resistance, K. A. Timiryazev Institute of Plant Physiology, \\ Russian Academy of Sciences, Botanicheskaya Street 35, 127276 Moscow, Russia; raldugina42@mail.ru \\ 5 Laboratory of Plant Protection, N.V. Tsitsin Main Botanical Garden of Russian Academy of Sciences, \\ Botanicheskaya 4, 127276 Moscow, Russia \\ * Correspondence: marat131084@rambler.ru; Tel.: +7-(499)-977-31-41
}

check for

updates

Citation: Khaliluev, M.R.;

Bogoutdinova, L.R.; Raldugina, G.N.; Baranova, E.N. A Simple and Effective Bioassay Method Suitable to Comparative In Vitro Study of Tomato Salt Tolerance at Early Development Stages. Methods Protoc. 2022, 5, 11. https://doi.org/10.3390/ mps5010011

Academic Editor: Fernando Albericio

Received: 25 December 2021

Accepted: 17 January 2022

Published: 19 January 2022

Publisher's Note: MDPI stays neutral with regard to jurisdictional claims in published maps and institutional affiliations.

Copyright: (C) 2022 by the authors. Licensee MDPI, Basel, Switzerland. This article is an open access article distributed under the terms and conditions of the Creative Commons Attribution (CC BY) license (https:// creativecommons.org/licenses/by/ $4.0 /)$.

\begin{abstract}
In vitro evaluation of tomato seeds and seedlings for salt tolerance has undoubted advantages (high productivity, as well as stability and reproducibility of the obtained experimental data due to the maintenance of constant controlled conditions) in comparison with open-field system and pot experiments. However, even high-quality seeds greatly differ in the uniformity of germination capacity and germination energy. Heterogeneous germination in the habit and developmental stage of plant material significantly distorts the obtaining of relevant experimental data suitable for correct interpretation. In our study, we propose a simple and effective bioassay method suitable to comparative in vitro study of tomato salt tolerance using shoot apex of seedlings at the early first-true-leaf stage. Shoot apexes cultured the on the root induction medium (RIM) supplemented with $0.2 \mathrm{mg} / \mathrm{L}$ indole-3-butyric acid (IBA) and $\mathrm{NaCl}$ at different concentrations (0-250 $\mathrm{mM} \mathrm{NaCl}$ ) revealed significant differences between two tomato genotypes (line YaLF and cv. Rekordsmen) at the organismal (measurements of $\mathrm{CO}_{2}$ gas exchange), organ (rhizogenesis frequency; number and length of de novo regenerated roots; root fresh (RFW) and dry (RDW) weights; shoot fresh (SFW) and dry (SDW) weights), tissue (the average cross-sectional area of epidermal and mesophylls cotyledonary cells) and cellular (ultrastructure of chloroplast and nuclear compartments) development levels. In addition, a quantitative comparison of proline and photosynthetic pigments contents under 75 and $150 \mathrm{~mm} \mathrm{NaCl}$ treatments showed a different response between two tomato genotypes. The proposed methodological approach can be used for other plants with a high response to auxin-induced rhizogenesis in vitro, as well as for the comparative in vitro assessment of other abiotic stresses.
\end{abstract}

Keywords: Solanum lycopersicum L.; $\mathrm{NaCl}$ stress in vitro; respiratory and photosynthetic $\mathrm{CO}_{2}$ gas exchange; proline; photosynthetic pigments; ultrastructure of cotyledon spongy mesophyll

\section{Introduction}

Globally, tomatoes (Solanum lycopersicum L.) are the second most important vegetable crops after potatoes and are used as a valuable source of vitamins and lycopene in fresh or processed tomato products [1,2]. In 2019, the world's total tomato fruit production was approximately 180.7 million tons, which accounts for $1.7 \%$ (3.0 million tons) from Russia. Russia ranks 11th in the world for tomatoes harvested area ( 81.3 thousand ha) [3]. Tomatoes are predominantly grown in the soil for open-field system $(80.4 \%$ from total tomato fruit 
production) in the south regions of the country (Krasnodar and Stavropol territories, as well as Volga and the central black earth regions), the lands of which are more or less subject to primary and/or secondary soil salinization.

In addition to its great practical value, the tomato has been widely used as a model plant in various basic research investigated the underlying the mechanisms of plant resistance to abiotic stresses, including salinity [4,5]. This is due to the large number of morphological traits clearly identifiable at different ontogenetic stages [6,7], detailed molecular genetic maps [8,9], and reproducible in vitro tissue culture techniques $[10,11]$.

The tomato (S. lycopersicum L.) is rated as a high salt sensitive crop. Plant growth inhibition, leading to significant reduction in tomato yield, occurs when the electrical conductivity (ECe) threshold of $2.5 \mathrm{dS} / \mathrm{m}$ [12], that corresponds to low salinity according to the FAO (USDA) soil classification $(\mathrm{ECe}=2.0-4.0 \mathrm{dS} / \mathrm{m})$ [13].

An important component underlying the mechanisms of plant resistance to salinity is comprehensive assessment based on biochemical, physiological, anatomical, genetic, and molecular responses. Creating and maintaining controlled conditions are an essential requirement to obtain reliability experimental data suitable for correct interpretation. This is due to the fact that environmental changes (temperature, relative humidity, light intensity, level of air pollution, etc.) dramatically affect a plant's response to salinity $[14,15]$. In vitro testing of plant genotypes under stress conditions devoid of all of the mentioned above disadvantages. Additionally, a comparative assessment for salinity tolerance, as well as screening of highly salinity-resistant genotypes, can be conducted already at the early development stages (seeds and seedlings), which are the most critical for tomatoes [16-18]. It is also important that a clear correlation between tomato salt tolerance under in vitro (callus) and in vivo (plants grown in greenhouse) conditions has been observed [18-20].

Many studies carried out to testing of tomato salinity tolerance during germination of non-sterile seeds under stress treatment [21-23] or aseptically seed germinated on culture media, containing various $\mathrm{NaCl}$ or $\mathrm{Na}_{2} \mathrm{SO}_{4}$ concentrations [24-27]. However, even high-quality seeds greatly differ in the uniformity of germination capacity and germination energy. Even greater differences in these parameters are observed after surface seed sterilization and in vitro germination. Plant material that is heterogeneous in habit and developmental stage significantly distorts the obtaining of relevant experimental data suitable for correct interpretation. In our study, we propose a simple and effective bioassay method suitable to comparative in vitro study of tomato salt tolerance using shoot apex of seedlings at the early first-true-leaf stage. This short-term bioassay method allows researchers to obtain correct experimental data for morphometric, physiological, biochemical and cytological analyzes at the cellular, tissue, organ, and organismal development levels.

\section{Materials and Methods}

\subsection{Plant Material and Obtaining of Aseptic Donor Seedlings}

The seeds of tomato ( $S$. lycopersicum L.) line YaLF, the male parental line for the commercial F1 Yunior hybrid, and cv. Rekordsmen were obtained from N.N. Timofeev breeding station, Russian State Agrarian University-Moscow Timiryazev Agricultural Academy (Moscow, Russia), as well as All-Russia Research Institute of Irrigated Vegetable, Melon and Ground Growing (Astrakhan oblast, Kamyziyak, Russia), respectively. F1 Yunior hybrid, and cv. Rekordsmen are recommended for cultivation in the greenhouse and open-field system, respectively. In vitro aseptic donor seedlings were produced by surface sterilization of tomato seeds in $96 \%$ ethanol for $30 \mathrm{~s}$ and in $20 \%$ water solution $(v / v)$ of a commercial bleach Ace $(5 \% \mathrm{NaOCl}$, Procter and Gamble, Saint Petersburg, Russia) supplemented with a $5 \mu \mathrm{L}$ of Tween-20 for $6-8 \mathrm{~min}$. The sterilized seeds were washed with distilled water four times for $1 \mathrm{~min}$ each and then germinated in culture vessels containing agar-solidified $(0.7 \%(w / v))$ MS basal medium [28] without plant growth regulators (PGR). The $\mathrm{pH}$ was adjusted to $5.7-5.8$ before autoclaving at $121^{\circ} \mathrm{C}$ for $20 \mathrm{~min}$. The cultures were maintained in a climate chamber WLR-351H (Sanyo, Japan) under 25/23 
(day/night) $\pm 1{ }^{\circ} \mathrm{C}$, with fluorescence light $\left(65 \mu \mathrm{mol} \mathrm{m}^{-2} \mathrm{~s}^{-1}\right)$ during long-day photoperiod (16 h light/8 h dark).

\subsection{Effects of $\mathrm{NaCl}$ Treatments on De Novo Root Formation in In Vitro Tomato Seedlings and Its Morphological Characteristics}

Roots and part of the hypocotyl were excised from 8-10-day-old aseptic tomato seedlings at the early first-true-leaf stage, after which shoot fragments $1.5-2 \mathrm{~cm}$ in length were transferred into culture vessels $\left(300 \mathrm{~cm}^{3}\right)$ containing root induction medium (RIM) (MS medium with half strength of macro and micro salts, vitamins, $2 \%(w / v)$ sucrose, $0.7 \%(w / v)$ agar, $0.2 \mathrm{mg} / \mathrm{L}$ indole-3-butyric acid (IBA) (Sigma, Saint-Louis, MO, USA) and $25-300 \mathrm{mM} \mathrm{NaCl}$ ) (Figure 1). RIM without $\mathrm{NaCl}$ was used as a control. IBA solution were dissolved in distilled water, filter-sterilized with MCE membrane $(0.22 \mu \mathrm{m}$ Millipore, Burlington, IA, USA) and stored until use at $-20^{\circ} \mathrm{C}$.
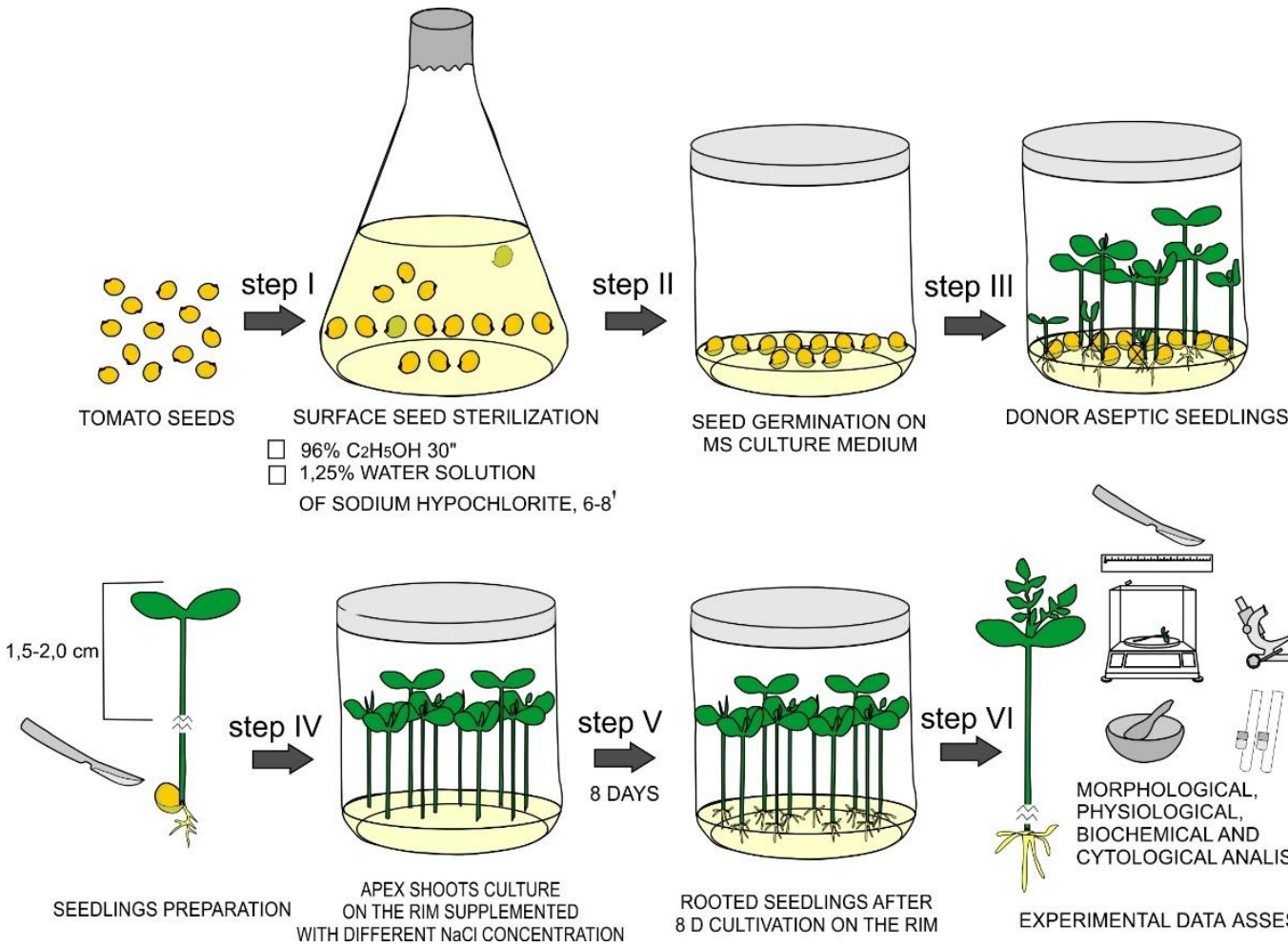
MS CULTURE MEDIUM

$1,25 \%$ WATER SOLUTION

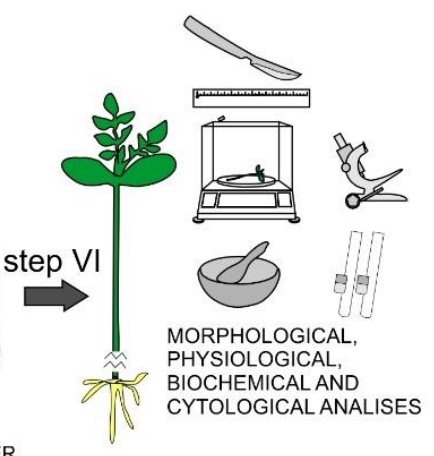

ROOTED SEEDLINGS AFTER 8 D CULTIVATION ON THE RIM

EXPERIMENTAL DATA ASSESSMENT

Figure 1. Experimental design for comparative in vitro assessment of tomato salt tolerance at early development stages.

After $8 \mathrm{~d}$ of in vitro culture, the evaluated morphological characteristics included the rhizogenesis frequency $(\%)$, number and length $(\mathrm{cm})$ of regenerated roots, root fresh (RFW) and dry (RDW) weights, as well as shoot fresh (SFW) and dry (SDW) weights. The rhizogenesis frequency (\%) was determined as the ratio between the number of seedlings with root formation and the total number of seedlings. In addition, time of the beginning root formation was noted. The FW and DW were determined gravimetrically using an analytical balance (Sartorius, Göttingen, Germany). To determine the DW, roots and shoots were dried at $65^{\circ} \mathrm{C}$ until a constant weight. Each variant of treatment $(n=10)$ was performed in three replications.

\subsection{Measurements of $\mathrm{CO}_{2}$ Gas Exchange}

Measurements of respiratory and photosynthetic $\mathrm{CO}_{2}$ gas exchange in in vitro tomato seedlings was carried out using earlier developed whole-plant chamber system [29,30]. This closed chamber system includes the following components connected in series: sealed 
culture vessels, pump, air dryer, rotameter, GOA-4 infrared gas analyzer (Khimavtomatika, Russia) with a $0-0.05 \% \mathrm{CO}_{2}$ scale, two-position gas switch for multiple measurements. The annular fluorescent lamp LUMILUX T9 L 32W/840 C G10Q (OSRAM, Germany) was applied for photosynthetic $\mathrm{CO}_{2}$ gas exchange measurements. Tomato seedlings of the studied genotypes after $8 \mathrm{~d}$ culture on $\mathrm{RIM}$ without $\mathrm{NaCl}$, as well as with the addition of experimentally established sublethal (150 and $250 \mathrm{mM} \mathrm{NaCl}$ for the line YaLF and cv. Rekordsmen, respectively) and intermediate $\mathrm{NaCl}$ concentrations were used for assessment. $24 \mathrm{~h}$ before measurements the culture vessels with tomato seedlings were unsealed and kept open under growth chamber. Seedlings were incubated in complete darkness $2 \mathrm{~h}$ before measurements. $\mathrm{CO}_{2}$ was recorded under dark and light conditions at a constant temperature $\left(22-23{ }^{\circ} \mathrm{C}\right)$ for $5 \mathrm{~min}$. Dark respiration rates (DRR) $\left(\mathrm{CO}_{2}\right.$ gas exchange $(\mu \mathrm{g} / \mathrm{h})$ in the darkness) and true photosynthetic rates (TPR) $\left(\mathrm{CO}_{2}\right.$ gas exchange $(\mu \mathrm{g} / \mathrm{h})$ under light and dark conditions) was determined per mg of seedling dry weight. Each variant of treatment $(n=10)$ was performed in three replications.

\subsection{Proline and Photosynthetic Pigment Contents}

Leaves of tomato seedlings cultured on the RIM supplemented with 0,75 , and $150 \mathrm{mM} \mathrm{NaCl}$ were used for biochemical assays.

Determination of free proline content was carried out with a ninhydrin-based protocol [31] with some modifications. Proline extraction was carried out by boiling a $200 \mathrm{mg}$ leafy sample in $4 \mathrm{~mL}$ distilled water, and after cooling a ninhydrin reagent (1.25 $\mathrm{g}$ ninhydrin, $20 \mathrm{~mL} 6 \mathrm{M} \mathrm{H}_{3} \mathrm{PO}_{4}, 30 \mathrm{~mL}$ glacial acetic acid) was added. The color intensity was determined by Specol-11 spectrophotometer (Carl Zeiss, Oberkochen, Germany) at a wavelength of $520 \mathrm{~nm}$ against a sample in which distilled water was added instead of the extract. The proline content ( $\mu \mathrm{M} \mathrm{g}^{-1}$ of FW) was determined from a calibration curve using proline (Serva, Heidelberg, Germany).

The photosynthetic pigment contents (chlorophylls a (Chla), b (Chlb)and carotenoids (Car)) were determined by extracting pigments from leaves with $96 \%$ ethyl alcohol [32]. The degree of solution absorption (optical density) for chlorophylls $a, b$, and carotenoids was determined using Genesys 20 spectrophotometer (ThermoScientific, Waltham, MA, USA) at a wavelength of 665,649 and $471 \mathrm{~nm}$, respectively. The pigment content $\left(\mu \mathrm{g} \mathrm{g}^{-1} \mathrm{FW}\right)$ was calculated by the formulas [33]:

$$
\begin{gathered}
\text { Cchl } \mathrm{a}=13.70 \mathrm{D}_{665}-5.76 \mathrm{D}_{649} ; \\
\mathrm{Cchl} \mathrm{b}=25.80 \mathrm{D}_{649}-7.60 \mathrm{D}_{665} ; \\
\text { Ccar }=\left(1000 \mathrm{D}_{471} \times 2.13 \mathrm{Cchl} \mathrm{a}-97.64 \mathrm{Cchl} \mathrm{b}\right) / 209 \\
\mathrm{~A}=\mathrm{C} * \mathrm{~V} / 1000 * \mathrm{n}
\end{gathered}
$$

where C, pigment concentrations; D, optical density; V, extract volume; and n, leaf fresh weight.

\subsection{Preparation of Cotyledon Samples for Light and Transmission Electron Microscopy (TEM)}

Excised samples from the middle part of the cotyledons (2-3 mm) were taken from seedlings after eight days culture on RIM including 0 (control), 75, and $150 \mathrm{mM} \mathrm{NaCl}$ and fixed for $24 \mathrm{~h}$ in 2.5\% glutaraldehyde (Merck, Darmstadt, Germany) dissolved in $0.1 \mathrm{M}$ Sorensen's phosphate buffer ( $\mathrm{pH} 7.2$ ) with 1.5\% sucrose. Then the samples were washed, post-fixed in 1\% OsO4 (Sigma-Aldrich, Saint-Louis, MO, USA), and dehydrated in ethanol of increasing concentrations (30,50, 70, 96, and 100\%) and in propylene oxide (Fluka, Darmstadt, Germany). The samples were embedded in Epon-812 and Araldite 502 mixture (Merck, Darmstadt, Germany) according to the standard procedure. For light microscopy, semi-thin sections $(1-2 \mu \mathrm{m})$ were prepared using glass knives and ultramicrotome LKB-V (LKB, Bromma, Sweden), placed on glass slides and embedded in epoxy resin. Samples were photographed using Olympus BX51 microscope (Olympus, Tokyo, Japan) equipped 
with Color View II camera (Soft Imaging System, Münster, Germany). The average crosssectional area of upper epidermis (UE), spongy (SM) and palisade (PM) mesophylls was determined using a Cell A software package (Olympus, Japan). At least 300 cells of mentioned above tissues from three independent seedlings for each experimental treatment were analyzed.

For electron microscopy, embedded samples were sectioned with ULTRA $45^{\circ}$ diamond knife (Diatom, Nidau, Switzerland), using LKB-V ultramicrotome (LKB, Bromma, Sweden), placed on formvar coated blends and stained with uranyl acetate and lead citrate [34]. Thin sections were analyzed and photographed with H-500 electron microscope (Hitachi, Tokyo, Japan) at accelerating potential of $75 \mathrm{kV}$.

\subsection{Statistical Treatments of Experimental Data}

Statistical treatments of experimental data were performed at $5 \%$ significance level using the analysis of variance (ANOVA) and Duncan's multiple range tests with AGROS software (version 2.11, Moscow, Russia), as well as standard MS Excel software packages.

\section{Results}

\subsection{Influence of Different $\mathrm{NaCl}$ Concentrations on the Number of Regenerated Roots and Their Morphological Characteristics}

$\mathrm{NaCl}$ concentrations that inhibit in vitro root organogenesis in the studied tomato genotypes during cultivation of seedlings on the RIM were determined. Thus, necrosis of the hypocotyl fragment in direct contact with the culture medium was observed on the 5th day of culture in the seedling of line YaLF under $200 \mathrm{mM} \mathrm{NaCl}$ exposure, which led to almost complete inhibition of root formation. A slight decrease of rhizogenesis frequency to $93.3 \%$ was demonstrated in fragments of tomato seedlings cv. Rekordsmen on RIM with a higher $\mathrm{NaCl}$ content $(250 \mathrm{mM})$, compared with YaLF line. High concentrations of $\mathrm{NaCl}$ (150 $\mathrm{mM}$ and more) not only reduced the rhizogenesis frequency, but also lengthened the timing of root formation (Table 1).

Table 1. The effects of different $\mathrm{NaCl}$ concentrations in culture medium on the rhizogenesis frequency and time of the beginning root formation from tomato seedlings.

\begin{tabular}{ccccc}
\hline \multirow{2}{*}{$\begin{array}{c}\text { NaCl } \\
\text { Concentrations, } \mathbf{m M}\end{array}$} & \multicolumn{2}{c}{ Rhizogenesis Frequency, $\%$} & \multicolumn{2}{c}{$\begin{array}{c}\text { Time of the Beginning Root } \\
\text { Formation, Days }\end{array}$} \\
\cline { 2 - 5 } & Line YaLF & cv. Rekordsmen & Line YaLF & cv. Rekordsmen \\
\hline 0 & 100 & 100 & 4 & 4 \\
25 & 100 & 100 & 4 & 4 \\
50 & 100 & 100 & 4 & 4 \\
75 & 100 & 100 & 4 & 4 \\
100 & 100 & 100 & 4 & 4 \\
150 & 100 & 100 & 5 & 6 \\
200 & 16,7 & 100 & 7 & 7 \\
250 & 0 & 93,3 & - & - \\
300 & nd & 0 & nd & \\
\hline
\end{tabular}

Notes: «-», no root formation; nd, not determined.

Dramatic genotypic differences by the number of regenerated roots and their length were revealed (Figure 2). The lowest concentration of $\mathrm{NaCl}$ in $\mathrm{RIM} \mathrm{(25} \mathrm{mM)} \mathrm{led} \mathrm{to} \mathrm{a}$ significant reduce the number of regenerated roots in seedlings YaLF line as compared to the control. At the same time, a significant increase in their length was observed. A subsequent reduction of in a root number in the tomato YaLF line was noted under $150 \mathrm{mM}$ $\mathrm{NaCl}$ treatment (Figure 2a). Compared to the controls, reduction in a root number of the cv. Rekordsmen seedlings occurred only under $150 \mathrm{mM} \mathrm{NaCl}$ exposure, and the minimal $\mathrm{NaCl}$ concentration did not lead to a significant increase in their length (Figure $2 \mathrm{~b}$ ). The formation of shortened roots in both tomato genotypes was revealed during the culture of seedlings on RIM supplemented with $\mathrm{NaCl}$ at concentrations of higher than $75 \mathrm{mM}$. 
(a)

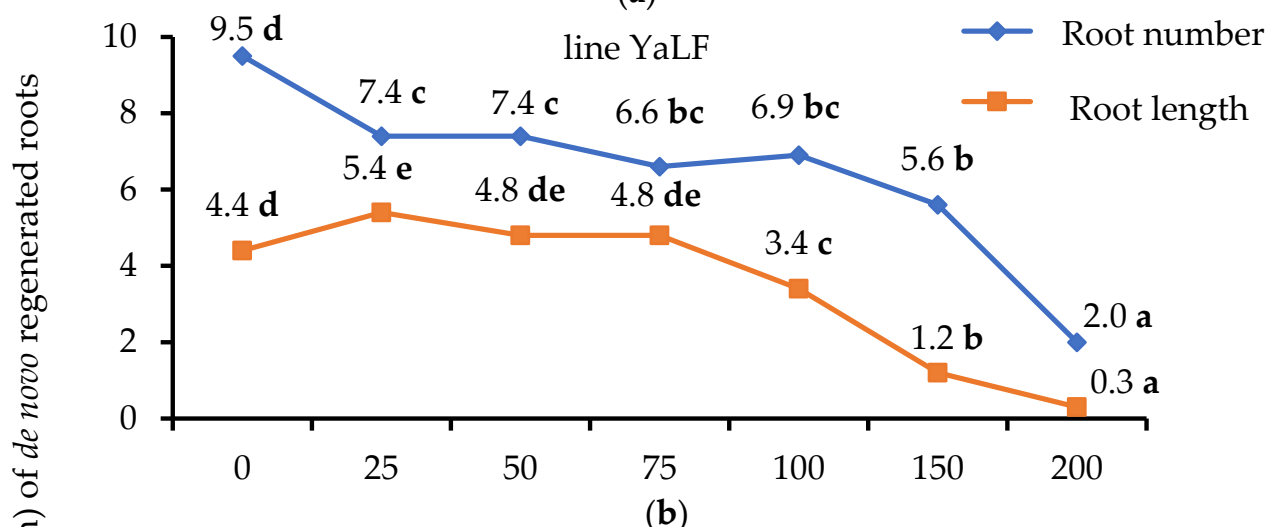

cv. Rekordsmen

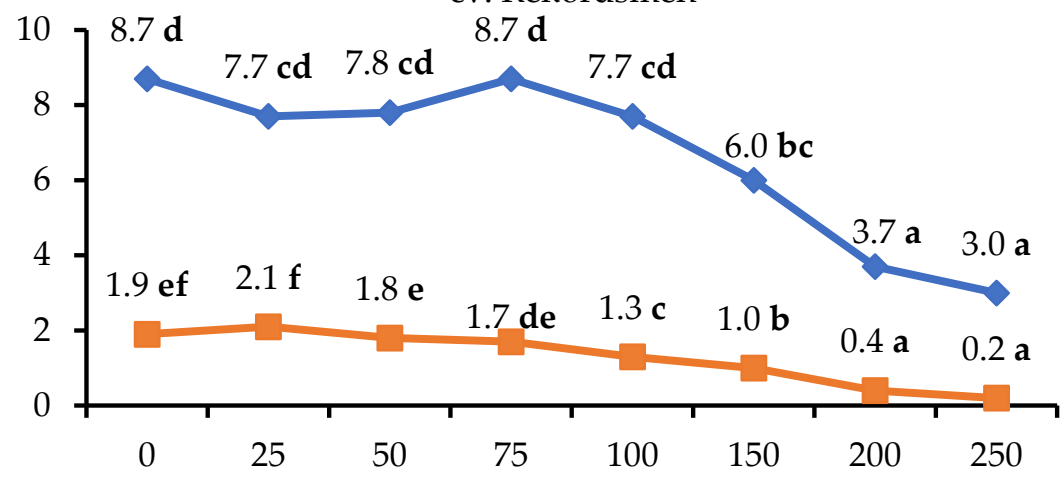

\section{$\mathrm{NaCl}$ concentration, $\mathrm{mM}$}

Figure 2. Influence of different $\mathrm{NaCl}$ concentrations in $\mathrm{RIM}$ on the number (units) and length (cm) of de novo regenerated roots in seedlings of the YaLF line (a) and cv. Rekordsmen (b). Means followed by the same letter are not significantly different at $\alpha=0.05$ according to the Duncan's multiple range test $(n=30)$.

Salinity treatments induced by $\mathrm{NaCl}$ had a significant effect on the root fresh weight (RFW) for two tomato genotypes (Table 2).

Table 2. The effects of different $\mathrm{NaCl}$ concentrations in RIM on the RFW and RDW.

\begin{tabular}{ccccc}
\hline \multirow{2}{*}{$\begin{array}{c}\text { NaCl } \\
\text { Concentrations, } \mathbf{m M}\end{array}$} & \multicolumn{2}{c}{ RFW, mg } & \multicolumn{2}{c}{ RDW, mg } \\
\cline { 2 - 5 } & Line YaLF & cv. Rekordsmen & Line YaLF & cv. Rekordsmen \\
\hline 0 & $17.68 \mathrm{l}$ & $15.97 \mathrm{kl}$ & $1.19 \mathrm{l}$ & $0.95 \mathrm{k}$ \\
25 & $14.08 \mathrm{jk}$ & $11.61 \mathrm{ij}$ & $0.78 \mathrm{ghijk}$ & $0.78 \mathrm{hijk}$ \\
50 & $7.44 \mathrm{fgh}$ & $8.37 \mathrm{gh}$ & $0.67 \mathrm{fghi}$ & $0.85 \mathrm{ijk}$ \\
75 & $6.54 \mathrm{efgh}$ & $8.37 \mathrm{~h}$ & $0.57 \mathrm{fg}$ & $0.91 \mathrm{jk}$ \\
100 & $4.78 \mathrm{cdef}$ & $5.39 \mathrm{defg}$ & $0.47 \mathrm{cdef}$ & $0.55 \mathrm{def}$ \\
150 & $1.77 \mathrm{ab}$ & $3.35 \mathrm{bcd}$ & $0.24 \mathrm{~b}$ & $0.55 \mathrm{ef}$ \\
200 & $0.07 \mathrm{a}$ & $0.91 \mathrm{ab}$ & $0.02 \mathrm{a}$ & $0.14 \mathrm{ab}$ \\
250 & - & $0.70 \mathrm{ab}$ & - & $0.08 \mathrm{ab}$
\end{tabular}

Notes: «-», no root formation. Means followed by the same letter are not significantly different at $\alpha=0.05$ according to the Duncan's multiple range test $(n=30)$.

An inverse relationship was found between RFW and intensity of $\mathrm{NaCl}$ salinity. At the same time, no significant differences were found between the studied tomato genotypes. On the contrary, dramatic genotypic differences by root dry weight (RDW) were found. In general, both tomato genotypes were characterized by a decrease in RDW with increasing 
$\mathrm{NaCl}$ concentration in the RIM. However, compared with the control, a significant decrease of RDW has already mentioned in culturing seedlings of the YaLF line on RIM supplemented with the lowest $\mathrm{NaCl}$ concentration $(25 \mathrm{mM})$, whereas for the $\mathrm{cv}$. Rekordsmen only under $150 \mathrm{mM} \mathrm{NaCl}$ salinity exposure.

\subsection{Influence of Different $\mathrm{NaCl}$ Concentrations on the Shoot Fresh Weight (SFW) and Shoot Dry} Weight (SDW)

The results of two-way ANOVA test showed statistical differences at $5 \%$ significance level in SFW and SDW between both the studied tomato genotypes and the $\mathrm{NaCl}$ concentrations in RIM. In addition, the differences were significant for interaction «genotype $\times$ culture medium». Generally, SFW of both tomato genotypes reduced with increasing of $\mathrm{NaCl}$ concentration in the RIM (Figure 3a). Differences between tomato genotypes were assessed in the $\mathrm{NaCl}$ concentration, at which there was a significant decrease in SFW compared to the control. Thus, these values were 50 and $75 \mathrm{mM} \mathrm{NaCl}$ for the line YaLF and $\mathrm{cv}$. Recordsmen, respectively. In addition, the SFW of cv. Rekordsmen was significantly higher than that of the line YaLF when the seedlings cultured on RIM containing $\mathrm{NaCl}$ at a concentration of $50 \mathrm{mM}$ and higher, with the exception of $100 \mathrm{mM} \mathrm{NaCl}$ exposure.

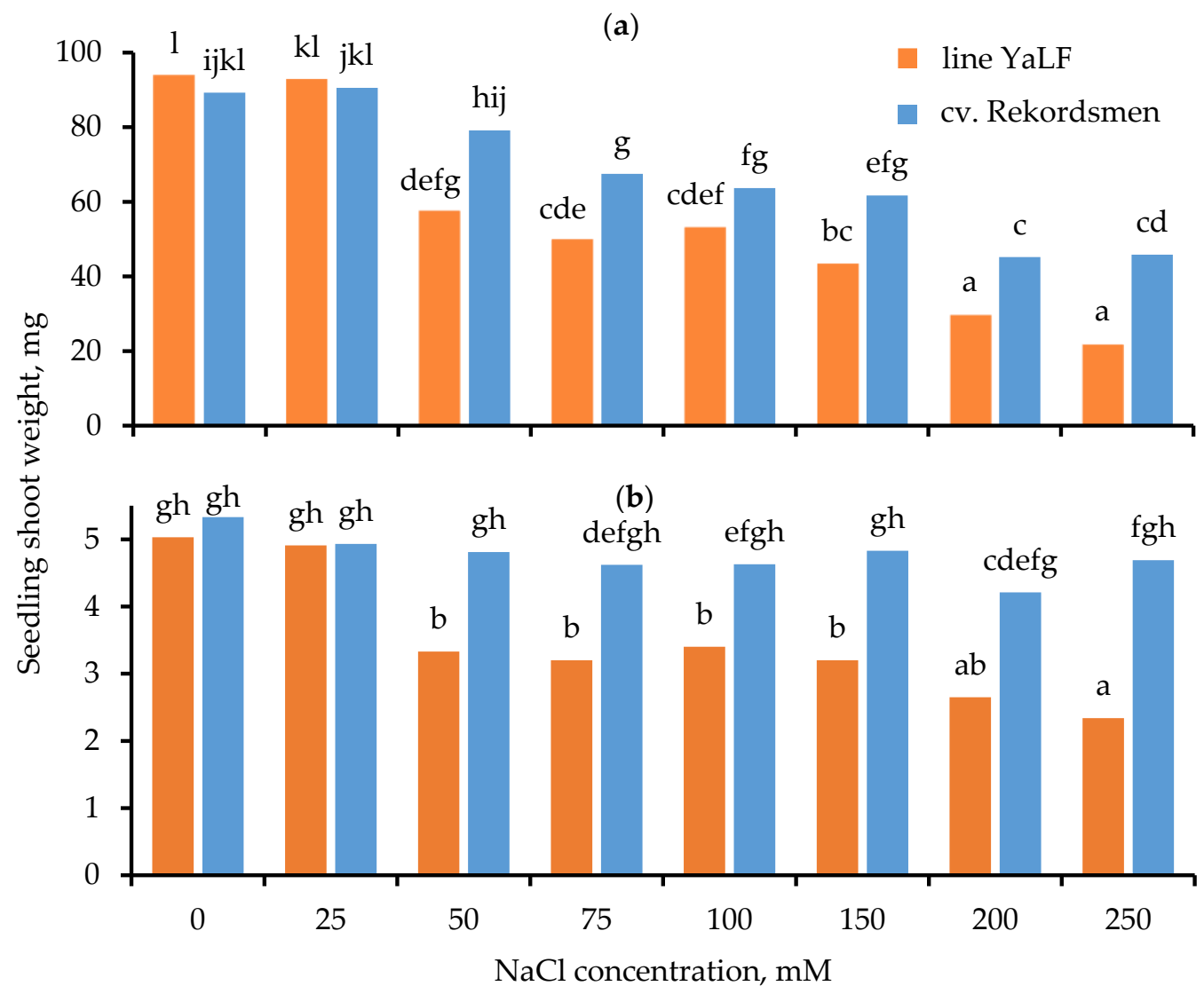

Figure 3. Influence of different $\mathrm{NaCl}$ concentrations in RIM on the SFW (a) and SDW (b) of tomato seedlings line YaLF and cv. Rekordsmen. Means followed by the same letter are not significantly different at $\alpha=0.05$ according to the Duncan's multiple range test $(n=30)$.

The dramatic difference between tomato genotypes was observed by a change in the SDW under salt treatments (Figure 3b). As in the case of the SFW, reduce of SDW in the line YaLF occurred under weak salinity $(50 \mathrm{mM} \mathrm{NaCl})$. On the contrary, there were no statistically significant differences between the control and experimental treatments for SDW in the cv. Rekordsmen. It should be noted that seedlings of both tomato genotypes cultured on the RIM containing $100 \mathrm{mM} \mathrm{NaCl}$ and higher had cotyledon with obvious signs of chlorosis, the extent of which becomes more pronounced under increased stressful 
salinity conditions. Moreover, the growth of true leaves was inhibited in tomato seedlings under moderate salinity $(100-150 \mathrm{mM} \mathrm{NaCl})$, while their formation did not occur by $200-250 \mathrm{mM} \mathrm{NaCl}$ treatments.

Accordingly, based on the mentioned above of experimental data sets on rhizogenesis frequency, as well as morphological characteristics of the tomato roots and shoots, sublethal concentrations 150 and $250 \mathrm{mM} \mathrm{NaCl}$ were revealed for the YaLF line and $\mathrm{cv}$. Rekordsmen, respectively.

\subsection{Influence of $\mathrm{NaCl}$ Salinity on the DRR and TPR}

Respiratory and photosynthetic $\mathrm{CO}_{2}$ gas exchange in in vitro tomato seedlings was assessed using intermediate and sublethal $\mathrm{NaCl}$ concentrations experimentally established for each genotype (Figure 4). Significant reduction of TPR and DRR (by 1.1 and 1.3 times, respectively) was observed during cultivation of tomato seedlings line YaLF under $75 \mathrm{mM}$ $\mathrm{NaCl}$ treatment compared to control. A subsequent decrease of TPR in seedlings line YaLF was noted on a RIM containing a sublethal $\mathrm{NaCl}$ concentration (Figure 4a). Compared with the line YaLF, significant differences in TPR and DRR for tomato seedlings of the cv. Rekordsmen between control conditions, as well as 75 and $150 \mathrm{mM} \mathrm{NaCl}$ treatments was not found. The change of respiratory and photosynthetic $\mathrm{CO}_{2}$ gas exchange in this genotype occurred only under $250 \mathrm{mM} \mathrm{NaCl}$ (Figure $4 \mathrm{~b}$ ).

(a)

line YaLF (b)

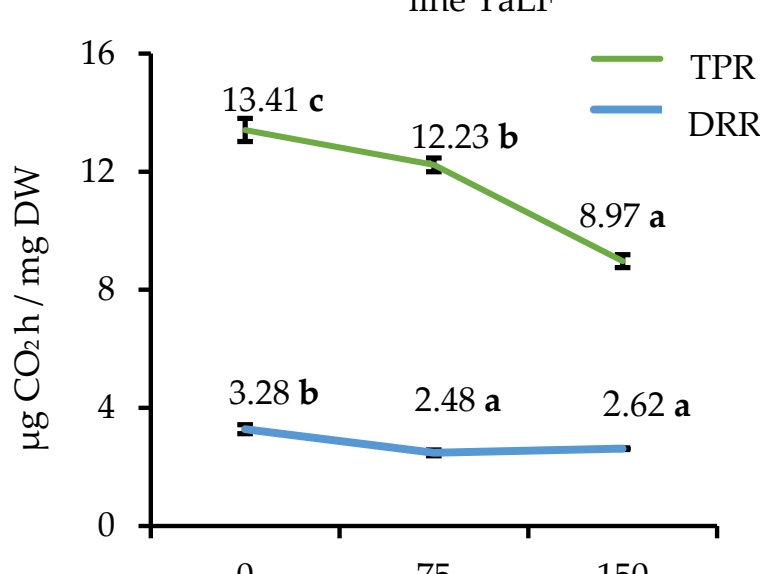

0 75 150

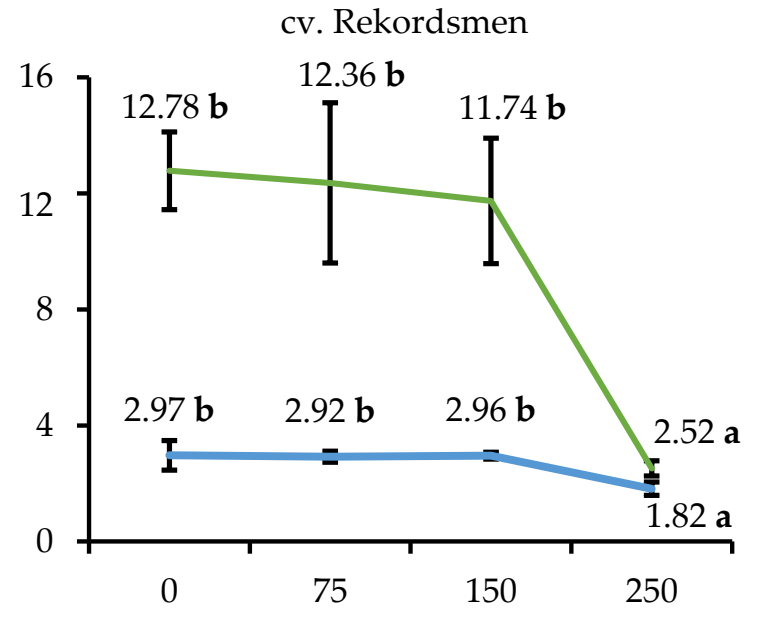

$\mathrm{NaCl}$ concentration, $\mathrm{mM}$

Figure 4. Influence of different $\mathrm{NaCl}$ concentrations in RIM on the TPR and DRR of tomato seedlings line YaLF (a) and cv. Rekordsmen (b). Means \pm standard errors followed by the same letter are not significantly different at $\alpha=0.05$ according to the Duncan's multiple range test $(n=30)$.

\subsection{Influence of $\mathrm{NaCl}$ Salinity on the Proline and Photosynthetic Pigment Contents}

The dramatic differences between tomato genotypes were observed by a change in the contents of proline and Chla under salt treatments (Figure 5a,b). Significant reduction of proline (by 1.4 and 3.1 times) and Chla (by 1.9 and 1.6 times) contents occurred during cultured of tomato seedlings line YaLF under 75 and $150 \mathrm{mM} \mathrm{NaCl}$ treatment compared to control. On the contrary, the content of proline in leaves of tomato cv. Rekordsmen significantly increased under $75 \mathrm{mM} \mathrm{NaCl}$, while the content of Chla under 75 and $150 \mathrm{mM}$ $\mathrm{NaCl}$ treatments did not differ from the control values. 
(a)

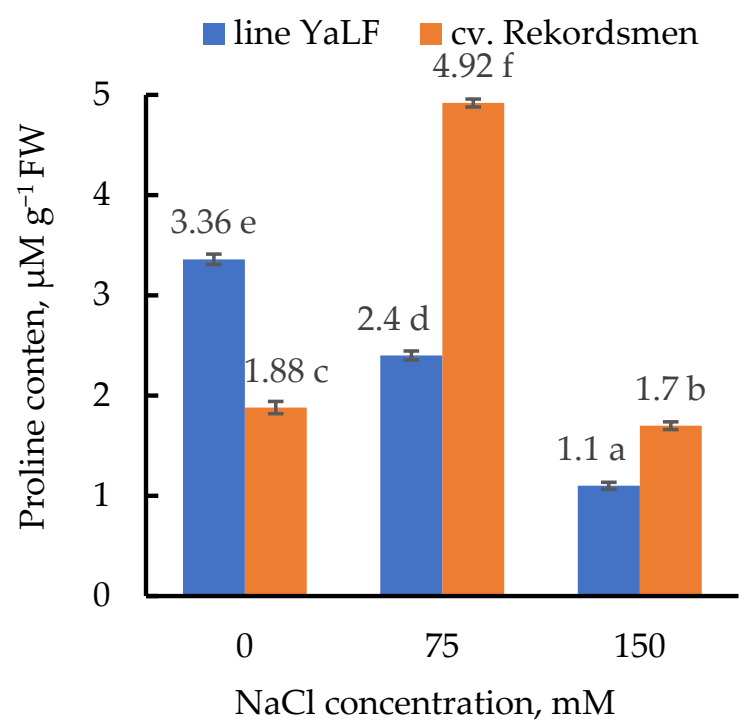

(c)

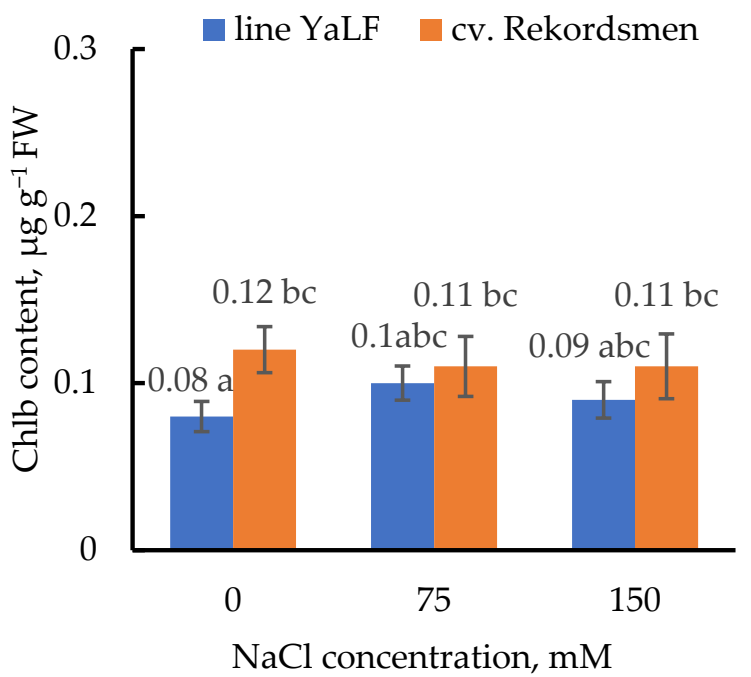

(b)

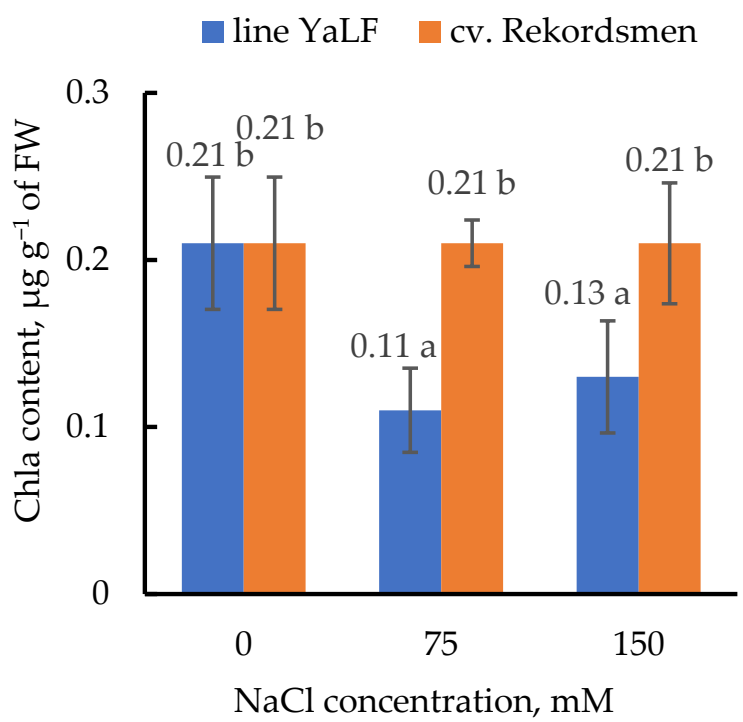

(d)

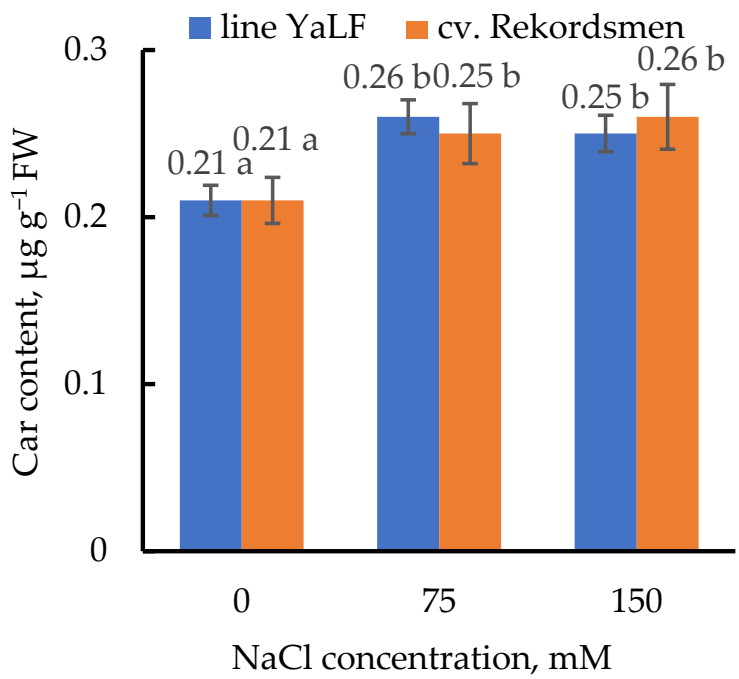

Figure 5. Influence of $\mathrm{NaCl}$ salinity on the content of proline (a), Chla (b) and Chlb (c), as well as Car (d) from tomato leaves. Means \pm standard errors at $\alpha=0.05$ according to ANOVA tests are presented.

Salinity did not change the Chlb content (Figure $5 c$ ) and significantly increased Car concentrations (Figure 5d) in tomato leaves of both genotypes.

3.5. The Morphological Response of Epidermal and Mesophylls Cotyledonary Tomato Cells to $\mathrm{NaCl}$ Salinity In Vitro

Generally, histological analysis revealed that the epidermal and mesophylls cotyledonary cells in plants of cv. Rekordsmen were less sensitive to presence of $\mathrm{NaCl}$ in the RIM, compared with line YaLF (Figure 6). Thus, cotyledonary UE cells in tomato line YaLF were characterized by gradual decrease the average cross-sectional area under $\mathrm{NaCl}$ salinity. Thus, the average cross-sectional area of UE under 75 and $150 \mathrm{mM} \mathrm{NaCl}$ were significantly less (1.2 and 1.4 times, respectively) compared to control conditions. A similar response of cotyledonary UE cells to $\mathrm{NaCl}$ treatments was observed in the tomato cv. Rekordsmen. However, $150 \mathrm{mM} \mathrm{NaCl}$ treatment resulted in a statistically increase in the cell size of this tissue compared with line YaLF. 


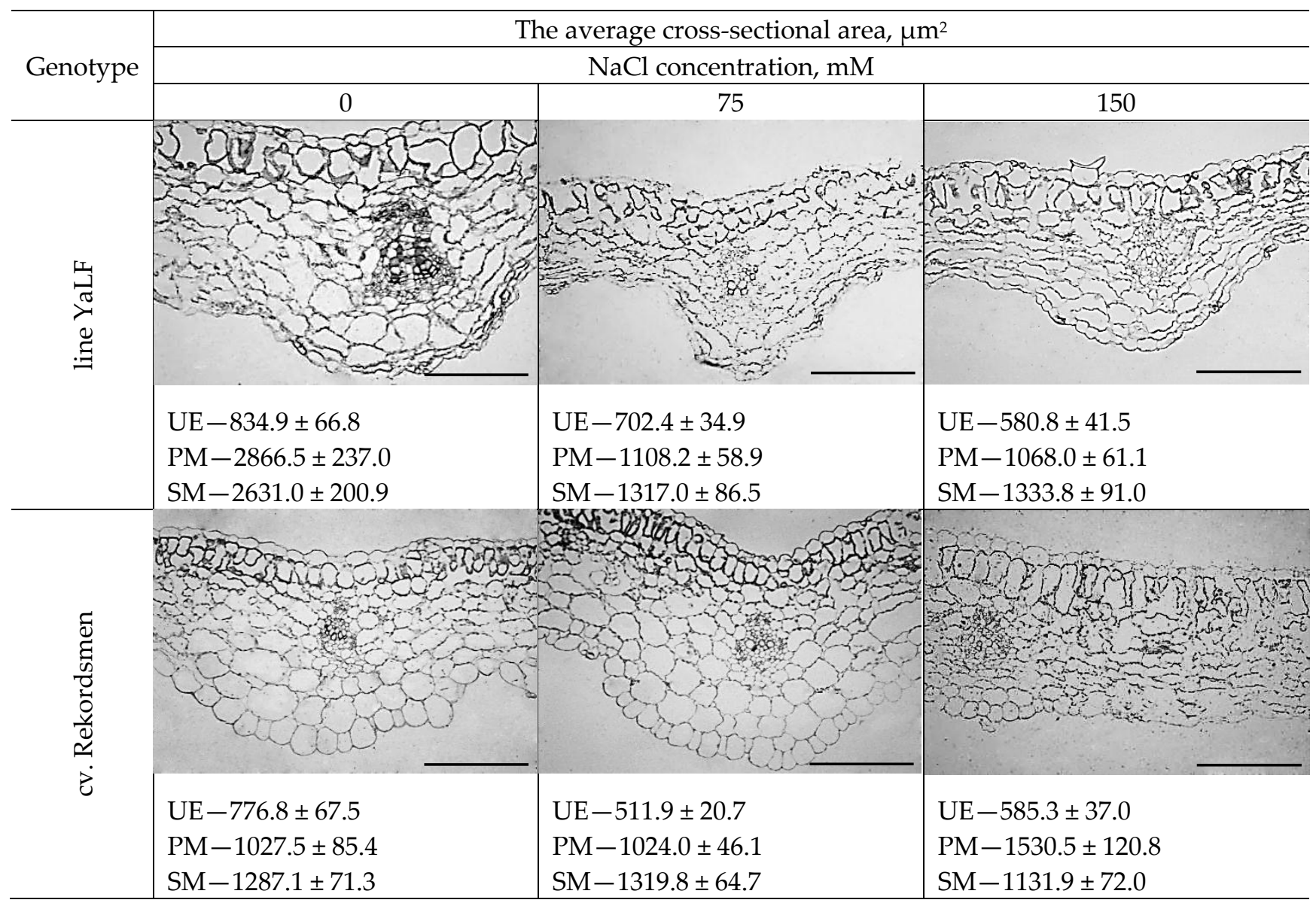

Figure 6. Comparison of a cotyledonous leaf cross-section at middle part from tomato seedlings line YaLF and cv. Rekordsmen after 8 d cultivation on the RIM supplemented with various $\mathrm{NaCl}(0,75$ and $150 \mathrm{mM}$ ) concentrations. UE, upper epidermis; PM, palisade mesophyll; SM, spongy mesophyll. Means of the average cross-sectional area \pm standard errors at $\alpha=0.05$ according to ANOVA tests are presented $(n \geq 300)$. Scale-100 $\mu \mathrm{m}$.

The dramatic differences between tomato genotypes in response to $\mathrm{NaCl}$ of cotyledonary SM and PM cells were also established. Shape and size (a decrease the average cell cross-sectional area by almost 2.6 and 2.7 times as compared to the control conditions) changes of the PM in line YaLF occurred under 75 and $150 \mathrm{mM} \mathrm{NaCl}$. An almost two-fold decrease in the average cross-sectional area of SM was also caused by these $\mathrm{NaCl}$ concentrations. Size of PM and SM cells in cotyledon leaves of cv. Rekordsmen under $75 \mathrm{mM}$ $\mathrm{NaCl}$ impact was unchanged. Compared with the line YaLF, $150 \mathrm{mM} \mathrm{NaCl}$ salinity caused approximately 1.5-fold increase in the average cross-sectional area of cotyledonary PM cells in tomato plants cv. Rekordsmen.

\subsection{Ultrastructure of Cotyledonary SM Cells from Control and Salt-Treated $(150 \mathrm{mM} \mathrm{NaCl})$ Tomato Seedlings}

The TEM images demonstrate the comparative structural organization of chloroplast and nuclear compartments in the cotyledonary SM cells of control and salt-treated $(150 \mathrm{mM} \mathrm{NaCl})$ tomato seedlings of the line YaLF (Figure 7) and cv. Rekordsmen (Figure 8). Under control conditions, chloroplasts located in a thin layer of cytoplasm between the cell wall and a large central vacuole have lenticular shape typical for this tissue. In chloroplasts, distinguishable thylakoid grana stacks and located between them stromal thylakoids, starch grains, plastoglobules, as well as small electron-lucent regions in the stroma containing nucleoids are clearly visible (Figures $7 \mathrm{a}$ and $8 \mathrm{a}$ ). The nucleus has a typical structure in the cotyledonary SM cells: a small granular nucleolus, a thin layer of tightly condensed 
chromatin organized in the nuclear periphery and associated with the nuclear membrane, and a nucleoplasm filled with dispersed and less packed euchromatin (Figures $7 \mathrm{~b}$ and 8b).
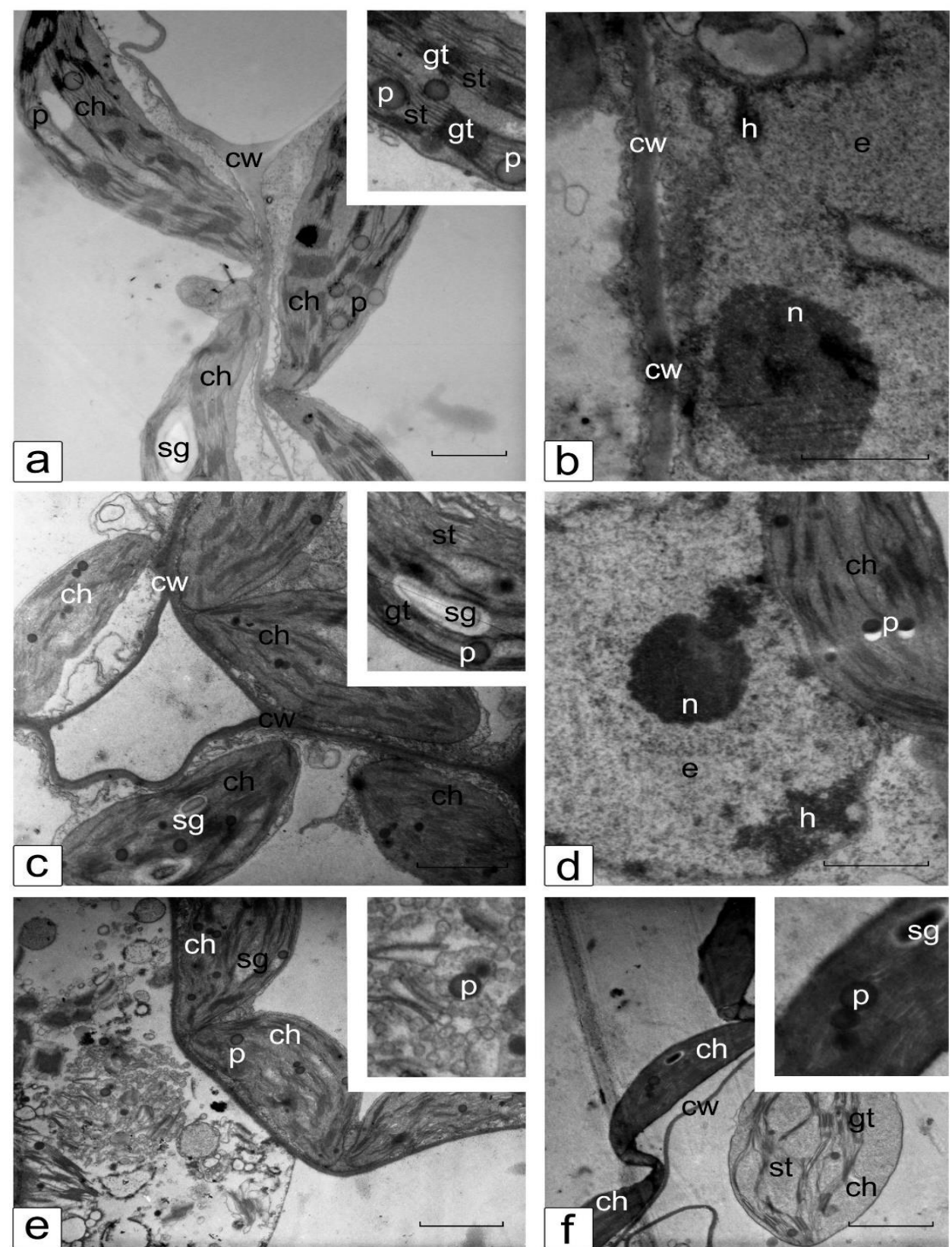

Figure 7. Ultrastructure of chloroplast $(\mathbf{a}, \mathbf{c}, \mathbf{e}, \mathbf{f})$ and nuclear $(\mathbf{b}, \mathbf{d})$ compartments in the cotyledonary SM cells of control $(\mathbf{a}, \mathbf{b})$ and salt-treated $(150 \mathrm{mM} \mathrm{NaCl})(\mathbf{c}-\mathbf{f})$ tomato seedlings of the line YaLF $\mathrm{Ch}$, chloroplast; gt, st, granal and stromal thylakoids, respectively; cw, cell wall; e, euchromatin; h, heterochromatin; $n$, nucleolus; $\mathrm{p}$, plastoglobuli; sg, starch grain. Scale, $1 \mu \mathrm{m}$. 

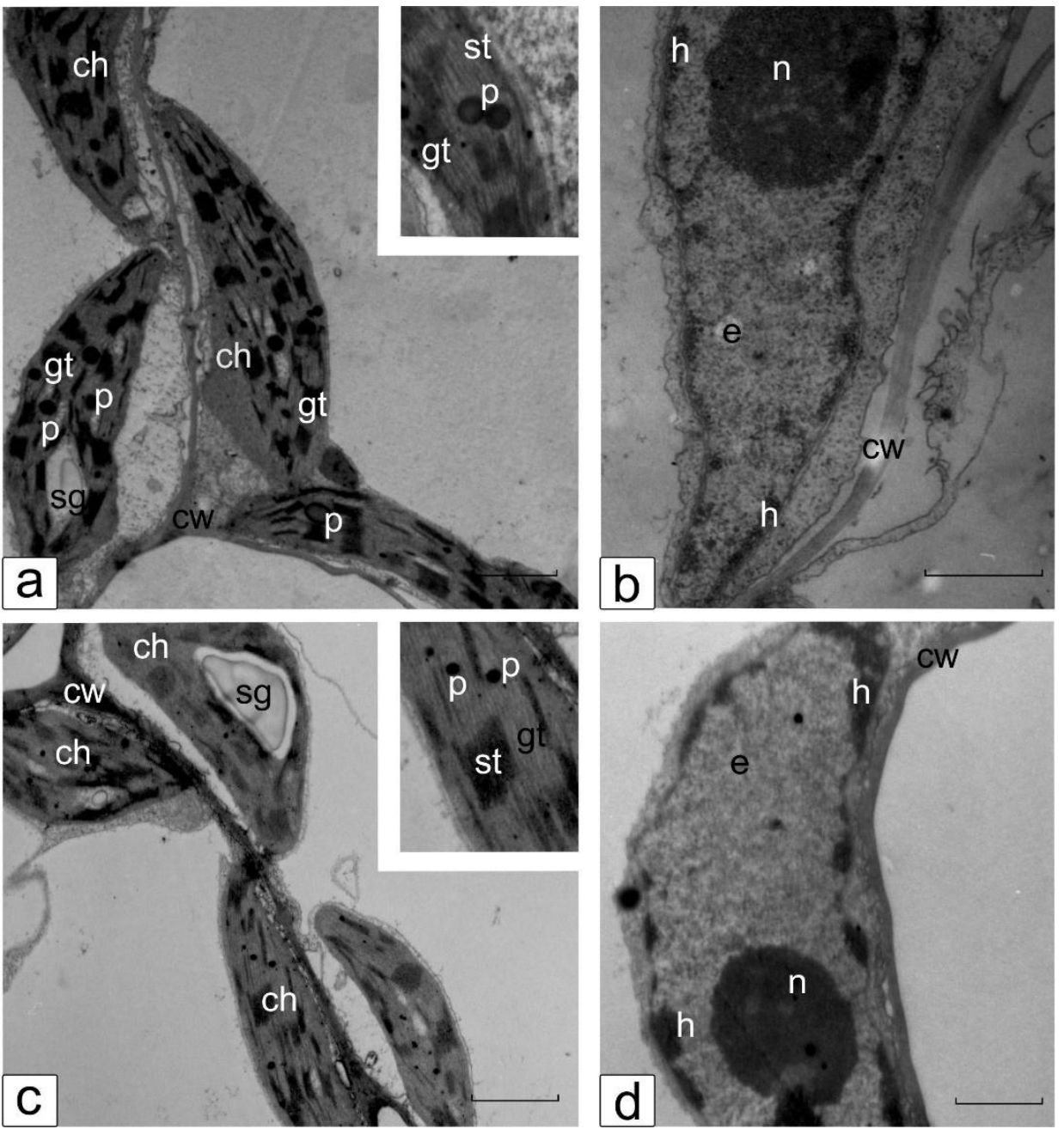

Figure 8. Ultrastructure of chloroplast $(\mathbf{a}, \mathbf{c})$ and nuclear $(\mathbf{b}, \mathbf{d})$ compartments in the cotyledonary $\mathrm{SM}$ cells of control $(\mathbf{a}, \mathbf{b})$ and salt-treated $(150 \mathrm{mM} \mathrm{NaCl})(\mathbf{c}, \mathbf{d})$ tomato seedlings $\mathrm{cv}$. Rekordsmen. Ch, chloroplast; gt, st, granal and stromal thylakoids, respectively; cw, cell wall; e, euchromatin; $h$, heterochromatin; n, nucleolus; $\mathrm{p}$, plastoglobuli; sg, starch grain. Scale, $1 \mu \mathrm{m}$.

Salinity-induced irreversible ultrastructural changes of some SM cells in line YaLF were established (Figure 7c,e). Figure $7 \mathrm{f}$ shows a part of a dead cell in which cytoplasm is completely absent. At the edge of the dead cells, swollen and rounded chloroplast is observed. Some SM cells showed clearly visible signs of convex plasmolysis, such as noticeable cytoplasmic invaginations, plasma membrane dissociation with the cell wall, and highly compacted chloroplasts with electron-dense thylakoids, which still maintain the plasma membrane integrity (Figure 7f). The noted ultrastructural disturbances indicate that $150 \mathrm{mM} \mathrm{NaCl}$ salinity leads to significant cell damage in the photosynthetic tissues of cotyledons line YaLF. These changes affect not only the structural and functional disturbances of the chloroplast and nuclear compartments, as well as the inhibition of biosynthetic processes in them (and also the death of a number of cells).

Chloroplasts in cotyledonary SM cells of the cv. Rekordsmen did not change in shape and structure under $150 \mathrm{NaCl}$ treatment compared with the line YaLF. The differences were found only in a decrease of size plastoglobuli (Figure 8c). The nuclear compartment also retained its characteristic shape and location under salinity. However, as in the case of YaLF line, structural changes in condensed chromatin (formation of large compacted lumps) occurred. The nucleolus contains fibrillar component with the lack of a granular component, which indicates disorders of ribosome biogenesis (Figure 8d). Thus, in comparison with the YaLF line, disorganization of the chloroplast and nuclear structure, leading to their 
destruction, does not occur in the cotyledonary SM cells of the cv. Rekordsmen under $150 \mathrm{mM} \mathrm{NaCl}$ treatment. The ultrastructural changes are due to metabolic disturbance caused by exposure to salt stress.

Thus, based on a comparative assessment, tomato cv. Rekordsmen characterized by enhanced resistance to $\mathrm{NaCl}$ salinity compared to the YaLF line on the organismal (TPR and DRR of seedlings), organ (rhizogenesis frequency; number and length of de novo regenerated roots; root fresh (RFW) and dry (RDW) weights; shoot fresh (SFW) and dry (SDW) weights), tissue (the average cross-sectional area of epidermal and mesophylls cotyledonary cells), and cellular (ultrastructure of chloroplast and nuclear compartments) development levels.

\section{Discussion}

Existing methods for assessment of tomato salt tolerance are divided into direct (tomato yield and productivity as well as biometric characteristics of plant growth and biomass; determination of seed germination under saline conditions) and indirect (physiological, biochemical, cytological and other characteristics that correlate with direct assessment indicators) assessments $[35,36]$. At the same time, comparative testing of tomato genotypes is carried out in the open-field system [37-39], as well as in pot experiments under greenhouse [40,41], hydroponic [42-46], or natural environmental conditions [47] (Figure 9). In addition, preliminary laboratory experiments are widely used to evaluate the salt tolerance of germinating tomato seeds or seedlings.

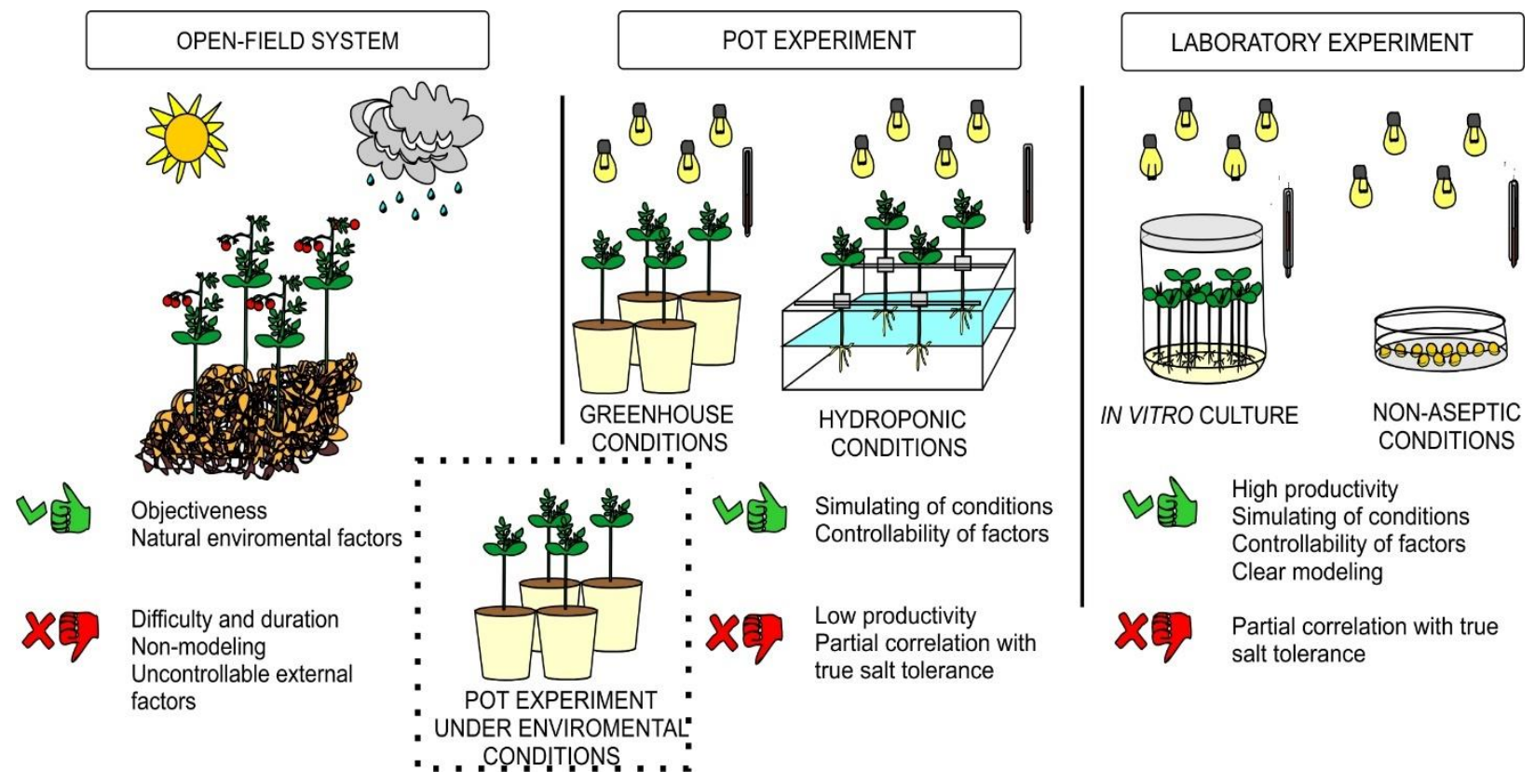

Figure 9. Methods for comparative assessment of tomato salt tolerance.

In vitro evaluation of tomato genotypes for salt tolerance has undoubted advantages (high productivity, as well as stability and reproducibility of the obtained experimental data due to the maintenance of constant controlled conditions) in comparison with openfield system and pot experiments (Figure 9). The authors cultivated seeds [21-23], shoot apexes [48], shoot apical meristem [49], and callus [50-53] as an explant source under salinity treatments in vitro. The disadvantage of seeds as an explant source is high heterogeneity, as well as greatly differ in the uniformity of germination capacity and germination energy. Callus tissue cells are also characterized by high heterogeneity. However, a number of studies have shown clear correlation between tomato salt tolerance under in vitro and in vivo conditions [18-20]. Heterogeneous plant material in habit and developmental stage significantly distorts of relevant experimental data suitable for correct interpretation 
under salinity in vitro. For a comparative in vitro study of tomato salt tolerance, we used shoot apex 1.5-2 cm in length of seedlings at the early first-true-leaf stage. Aseptic donor seedlings of two tomato genotypes (line YaLF and cv. Rekordsmen) of different ecological and geographical origin (Central and Volgo-Vyatka regions of Russia, respectively) were used. The soil salinity levels of these regions differ significantly, as a result of which the studied genotypes may differ significantly in salinity tolerance. Thus, more than $31 \%$ of the soils in the Astrakhan region are characterized by a high salinity (the concentration of sodium and sulfate ions reaches up to 7.1 and $12.5 \mathrm{mM}$ per $100 \mathrm{~g}$ of soil, respectively), as well as about $20 \%$ of solonetzic soil complexes [54]. This assumption was used as the basis for the choice of plant material.

The proposed methodological bioassay made it possible to reveal significant differences between tomato genotypes for salt tolerance using various morphological, physiological, biochemical and cytological characteristics. Cultivation of the shoot apexes on the RIM supplemented with various $\mathrm{NaCl}$ concentrations revealed significant differences between tomato genotypes at the whole organism (TPR and DRR of seedlings), organ (rhizogenesis frequency; number and length of de novo regenerated roots; root fresh (RFW) and dry (RDW) weights; shoot fresh (SFW) and dry (SDW) weights), tissue (the average cross-sectional area of epidermal and mesophylls cotyledonary cells) and cellular (ultrastructure of chloroplast and nuclear compartments) development levels. In addition, a quantitative comparison of proline and photosynthetic pigments contents under 75 and $150 \mathrm{~mm} \mathrm{NaCl}$ treatments showed a different response between tomato genotypes. Determined rhizogenesis-inhibiting $\mathrm{NaCl}$ concentrations and morphometric characteristics of regenerated roots under $\mathrm{NaCl}$-salinity suggest that root growth is the most indicative parameter for evaluating tomato salt tolerance in vitro $[47,53]$. The presented effective bioassay method was previously tested for evaluating some qualitative and quantitative cytological characterization of tomato roots (cv. Rekordsmen) de novo regenerated under 25-250 mM NaCl salinity [55], as well as for comparative anatomical and morphological studies of the epidermal and cortical parenchyma hypocotyl cells of tomato line YaLF and cv. Rekordsmen [56].

\section{Conclusions}

Therefore, we have developed and tested a simple and effective bioassay method suitable to comparative in vitro study of tomato salt tolerance using shoot apex of seedlings at the early first-true-leaf stage. This short-term bioassay method allows researchers to obtain correct experimental data for morphometric, physiological, biochemical, and cytological analyses at the different organization levels. The proposed methodological approach can be used for other plants with a high response to auxin-induced rhizogenesis in vitro. In addition, it can also be useful for the comparative in vitro assessment of other abiotic stresses, such as exposure to heavy metals or PEG-induced osmotic stress, as well as for a comparative assessment of control and transgenic plants expressing heterologous genes.

Author Contributions: M.R.K. and L.R.B. conducted the experiments on tomato culture in vitro; L.R.B. and G.N.R. determined content of proline and photosynthetic pigment; Preparation of plant material for light and transmission electron microscopy (E.N.B. and L.R.B.); Measurements of $\mathrm{CO}_{2}$ gas exchange (M.R.K. and E.N.B.); M.R.K. participated in manuscript conceptualization and statistical analysis of experimental data and writing, reviewing, and editing of manuscript, approved the final manuscript for publication, and agreed to be accountable for all aspects of the manuscript. All authors have read and agreed to the published version of the manuscript.

Funding: The reported study was supported by assignments 0574-2019-0002 (All-Russia Research Institute of Agricultural Biotechnology) and 18-118021490111-5 (Tsitsin Main Botanical Garden of Russian Academy of Sciences) of the Ministry of Science and Higher Education of the Russian Federation.

Institutional Review Board Statement: Not applicable.

Informed Consent Statement: Not applicable. 
Data Availability Statement: Data sharing is not applicable to this article.

Acknowledgments: The authors are grateful to Eduard N. Akanov for assistance in measurements and results interpretation of $\mathrm{CO}_{2}$ gas exchange.

Conflicts of Interest: The authors declare no conflict of interest.

\section{References}

1. Quinet, M.; Angosto, T.; Yuste-Lisbona, F.J.; Blanchard-Gros, R.; Bigot, S.; Martinez, J.P.; Lutts, S. Tomato fruit development and metabolism. Front. Plant Sci. 2019, 10, 1554. [CrossRef]

2. Massantini, R.; Radicetti, E.; Frangipane, M.T.; Campiglia, E. Quality of Tomato (Solanum lycopersicum L.) changes under different cover crops, soil tillage and nitrogen fertilization management. Agriculture 2021, 11, 106. [CrossRef]

3. Food and Agriculture Organization (FAO). Tomato Production in Russian Federation. Available online: http://www.fao.org/ faostat/en/\#data/QCL (accessed on 10 December 2021).

4. Abbasi, S.; Sadeghi, A.; Omidvari, M.; Tahan, V. The stimulators and responsive genes to induce systemic resistance against pathogens: An exclusive focus on tomato as a model plant. Biocatal. Agric. Biotechnol. 2021, 33, 101993. [CrossRef]

5. Anwar, R.; Fatima, T.; Mattoo, A. Tomatoes: A Model Crop of Solanaceous Plants; Oxford University Press: Oxford, UK, 2019.

6. Salim, M.M.R.; Rashid, M.H.; Hossain, M.M.; Zakaria, M. Morphological characterization of tomato (Solanum lycopersicum L.) genotypes. J. Saudi Soc. Agric. Sci. 2020, 19, 233-240. [CrossRef]

7. Athinodorou, F.; Foukas, P.; Tsaniklidis, G.; Kotsiras, A.; Chrysargyris, A.; Delis, C.; Kyratzis, A.C.; Tzortzakis, N.; Nikoloudakis, N. morphological diversity, genetic characterization, and phytochemical assessment of the cypriot tomato germplasm. Plants 2021, 10, 1698. [CrossRef]

8. Foolad, M.R. Genome mapping and molecular breeding of tomato. Int. J. Plant Genom. 2007, 2007, 064358. [CrossRef]

9. Szczechura, W.; Staniaszek, M.; Habdas, H. Tomato Molecular Markers. J. Fruit Ornam. Plant Res. 2011, 74, 5-23. [CrossRef]

10. Gerszberg, A.; Hnatuszko-Konka, K.; Kowalczyk, T.; Kononowicz, A.K. Tomato (Solanum lycopersicum L.) in the service of biotechnology. Plant Cell Tissue Organ Cult. 2015, 120, 881-902. [CrossRef]

11. Bhatia, P.; Ashwath, N.; Senaratna, T.; Midmore, D. Tissue culture studies of tomato (Lycopersicon esculentum). Plant Cell Tissue Organ Cult. 2004, 78, 1-21. [CrossRef]

12. Chinnusamy, V.; Jagendorf, A.; Zhu, J.K. Understanding and improving salt tolerance in plants. Crop Sci. 2005, 45, 437-448. [CrossRef]

13. Shirokova, Y.; Forkutsa, I.; Sharafutdinova, N. Use of electrical conductivity instead of soluble salts for soil salinity monitoring in central asia. Irrig. Drain. Syst. 2000, 14, 199-206. [CrossRef]

14. Singh, M.; Nara, U.; Kumar, A.; Choudhary, A.; Singh, H.; Thapa, S. Salinity tolerance mechanisms and their breeding implications. J. Gen. Eng. Biotechnol. 2021, 19, 1-18. [CrossRef] [PubMed]

15. Munns, R.; Tester, M. Mechanisms of salinity tolerance. Annu. Rev. Plant Biol. 2008, 59, 651-681. [CrossRef] [PubMed]

16. Li, J.; Liu, L.; Bai, Y.; Zhang, P.; Finkers, R.; Du, Y.; Visser, R.G.F.; van Heusden, A.W. Seedling salt tolerance in tomato. Euphytica 2011, 178, 403-414. [CrossRef]

17. Kaveh, H.; Nemati, H.; Farsi, M.; Jartoodeh, S.V. How salinity affect germination and emergence of tomato lines. J. Biol. Environ. Sci. 2011, 5, 159-163.

18. Cuartero, J.; Bolarin, M.C.; Asins, M.J.; Moreno, V. Increasing salt tolerance in the tomato. J. Exp. Bot. 2006, 57, 1045-1058. [CrossRef]

19. Alfocea, F.P.; Estan, M.T.; Caro, M.; Bolarín, M.C. Response of tomato cultivars to salinity. Plant Soil 1993, 150, 203-211. [CrossRef]

20. Cano, E.A.; Pérez-Alfocea, F.; Moreno, V.; Caro, M.; Bolarín, M.C. Evaluation of salt tolerance in cultivated and wild tomato species through in vitro shoot apex culture. Plant cell, tissue and organ culture. Plant Cell Tissue Organ Cult. 1998, 53, 19-26. [CrossRef]

21. Rofekuggaman, M.; Kubra, K.; Mahmood, S. Effect of different salt concentrations (NaCl) on seed germination and seedling growth of tomato cv. BINA Tomato-10. Asian Plant Res. J. 2020, 5, 38-44. [CrossRef]

22. Kumar, A.; Jain, K.; Kumar, M.; Shamim, M.; Kumar, J.; Kumar, A. Assessment of NaCl-induced stress in tomato (Lycopersicon esculentum L.). Eur. J. Med. Plants 2021, 32, 41-47. [CrossRef]

23. Chakma, P.; Hossain, M.M.; Rabbani, M.G. Effects of salinity stress on seed germination and seedling growth of tomato. $J$. Bangladesh Agric. Univ. 2019, 17, 490-499. [CrossRef]

24. Singh, J.; Sastry, E.D.; Singh, V. Effect of salinity on tomato (Lycopersicon esculentum Mill.) during seed germination stage. Physiol. Mol. Biol. Plants 2012, 18, 45-50. [CrossRef]

25. Sané, A.K.; Diallo, B.; Kane, A.; Sagna, M.; Sané, D.; Sy, M.O. In vitro germination and early vegetative growth of five tomato (Solanum lycopersicum L.) varieties under salt stress conditions. Am. J. Plant Sci. 2021, 12, 796-817. [CrossRef]

26. Yokaş, İ.; Tuna, A.L.; Bürün, B.; Altunlu, H.; Altan, F.; Kaya, C. Responses of the tomato (Lycopersicon esculentum Mill.) plant to exposure to different salt forms and rates. Turk. J. Agricult. For. 2008, 32, 319-329.

27. Seth, R.; Kendurkar, S. In vitro screening: An effective method for evaluation of commercial cultivars of tomato towards salinity stress. Int. J. Curr. Microbiol. App. Sci. 2015, 4, 725-730. 
28. Murashige, T.; Skoog, F. A revised medium for rapid growth and bioassays with tobacco tissue culture. Physiol. Plant. 1962, 15, 473-497. [CrossRef]

29. Baranova, E.N.; Khaliluev, M.R.; Akanov, E.N.; Gulevich, A.A.; Khalilueva, N.M.; Kurenina, L.V. System for Control of Photosynthetic and Respiratory $\mathrm{CO}_{2}$-Gas Exchange of Plants, Isolated Organs and Tissues in Vitro. RU Patent 2572349, 10 January 2016.

30. Baranova, Y.N.; Akanov, E.N.; Gulevich, A.A.; Kurenina, L.V.; Danilova, S.A.; Khaliluev, M.R. Dark respiration rate of transgenic tomato plants expressing FeSOD1 gene under chloride and sulfate salinity. Russ. Agric. Sci. 2014, 40, 14-17. [CrossRef]

31. Bates, L.S.; Waldren, R.P.; Teare, I.D. Rapid determination of free proline for water-stress studies. Plant Soil 1973, 39, 205-207. [CrossRef]

32. Shlyk, A.A. Definition of a Chlorophyll and Carotenoids in Extracts of Green Leaves. Biochemical Methods in Physiology of Plants; Nauka: Moscow, Russia, 1971.

33. Lichtenthaler, H.K. Chlorophylls and carotenoids: Pigments of photosynthetic biomembranes. Methods Enzymol. 1987, 148, 350-382.

34. Reynolds, E.S. The use of lead citrate at high pH as an electron-opaque stain in electron microscopy. J. Cell Biol. 1963, 17, 208-212. [CrossRef] [PubMed]

35. Alsadon, A.A.; Ibrahim, A.A.; Wahb-Allah, M.A.; Ali, A.A.M.; Sadder, M.T. Tomato under salinity stress: Correlation between growth and yield components and responsive genes. Acta Hortic. 2014, 1081, 111-119. [CrossRef]

36. Cuartero, J.; Fernández-Muñoz, R. Tomato and salinity. Sci. Hortic. 1998, 78, 83-125. [CrossRef]

37. Huang, C.; Peng, F.; You, Q.; Xue, X.; Wang, T.; Liao, J. Growth, yield and fruit quality of cherry tomato irrigated with saline water at different developmental stages. Acta Agric. Scand. Sect. B Soil Plant Sci. 2016, 66, 317-324. [CrossRef]

38. Kahlaoui, B.; Hachicha, M.; Rejeb, S.; Rejeb, M.N.; Hanchi, B.; Misle, E. Effects of saline water on tomato under subsurface drip irrigation: Nutritional and foliar aspects. J. Soil Sci. Plant Nutr. 2011, 11, 69-86. [CrossRef]

39. Rahil, M.; Hajjeh, H.; Qanadillo, A. Effect of saline water application through different irrigation intervals on tomato yield and soil properties. Open J. Soil Sci. 2013, 3, 143-147. [CrossRef]

40. Del Amor, F.M.; Martinez, V.; Cerda, A. Salt tolerance of tomato plants as affected by stage of plant development. Hortic. Sci. 2001, 36, 1260-1263. [CrossRef]

41. Suarez, D.L.; Celis, N.; Ferreira, J.F.; Reynolds, T.; Sandhu, D. Linking genetic determinants with salinity tolerance and ion relationships in eggplant, tomato and pepper. Sci. Rep. 2021, 11, 1-17. [CrossRef]

42. Ahmad, M.; Shoukat, A.; Anjum, M.; Kamran, M.; Saeed, M.Q.; Hussain, R.; Abbas, M.H. Assessment of tomato genotypes against salinity on the basis of morphological and physiological parameters in hydroponic conditions. Nat. Sci. 2019, $17,56-70$.

43. Pailles, Y.; Awlia, M.; Julkowska, M.; Passone, L.; Zemmouri, K.; Negrão, S.; Schmöckel, S.M.; Tester, M. Diverse traits contribute to salinity tolerance of wild tomato seedlings from the Galapagos Islands. Plant Physiol. 2020, 182, 534-546. [CrossRef]

44. Ali, A.A.M.; Romdhane, W.B.; Tarroum, M.; Al-Dakhil, M.; Al-Doss, A.; Alsadon, A.A.; Hassairi, A. Analysis of salinity tolerance in tomato introgression lines based on morpho-physiological and molecular traits. Plants 2021, 10, 2594. [CrossRef]

45. Loudari, A.; Benadis, C.; Naciri, R.; Soulaimani, A.; Zeroual, Y.; Gharous, M.E.; Kalaji, H.M.; Oukarroum, A. Salt stress affects mineral nutrition in shoots and roots and chlorophyll a fluorescence of tomato plants grown in hydroponic culture. J. Plant Int. 2020, 15, 398-405. [CrossRef]

46. Zaki, H.E.; Yokoi, S. A comparative in vitro study of salt tolerance in cultivated tomato and related wild species. Plant Biotech. 2016, 33, 361-372. [CrossRef]

47. Rahman, M.M.; Hossain, M.; Hossain, K.F.B.; Sikder, M.T.; Shammi, M.; Rasheduzzaman, M.; Hossain, M.A.; Alam, M.; Uddin, M.K. Effects of NaCl-salinity on tomato (Lycopersicon esculentum Mill.) plants in a pot experiment. Open Agric. 2018, 3, 578-585. [CrossRef]

48. Mahmoodzadeh, H. Ultrastructural changes in shoot apical meristem of canola (Brassica napus cv. Symbol) treated with sodium chloride. Pak. J. Biol. Sci. 2008, 11, 1161-1164. [CrossRef]

49. de Jonge, J. Shoot Apical Meristem Arrest in Brassica and Tomato. Ph.D. Thesis, Wageningen University and Research, Wageningen, The Netherlands, 16 December 2013.

50. El-Meleigy, E.A.; Gabr, M.F.; Mohamed, F.H.; Ismail, M.A. Responses to $\mathrm{NaCl}$ salinity of tomato cultivated and breeding lines differing in salt tolerance in callus cultures. Int. J. Agric. Biol. 2004, 6, 19-26.

51. Mahdi, E.F.M.; Idris, T.I.M. The effects of $\mathrm{NaCl}$ pre-treatment on salt tolerance of tomato (Lycopersicon esculentum Mill.) callus grown under elevated saline conditions. Int. Res. J. Biotech. 2013, 4, 61-67.

52. Nahar, L.L.; Nasar, M.Z.; Al Nayem, C.; Ashrafuzzaman, M. In Vitro growth media effect for regeneration of tomato (Lycopersicon esculentum) and evaluation of the salt tolerance activity of callus. J. Agric. Sustain. 2013, 3, 132-143.

53. Cano, E.A.; Pérez-Alfocea, F.; Moreno, V.; Bolarin, M.C. Responses to $\mathrm{NaCl}$ stress of cultivated and wild tomato species and their hybrids in callus cultures. Plant Cell Rep. 1996, 15, 791-794. [CrossRef]

54. Salina, Y.B.; Tyutyuma, N.V.; Tyutyuma, A.V. Salinization as a critical factor of land fertility in the Astrakhan region. Dostizheniya Nauk. Tekh. APK 2018, 32, 5-8. (In Russian) 
55. Bogoutdinova, L.R.; Baranova, E.N.; Baranova, G.B.; Kononenko, N.V.; Lazareva, E.M.; Smirnova, E.A.; Khaliluev, M.R. Morphobiological and cytological characterization of tomato roots (Solanum lycopersicum L., cv. Rekordsmen) regenerated under $\mathrm{NaCl}$ salinity in vitro. Cell Tissue Biol. 2020, 14, 228-242. [CrossRef]

56. Bogoutdinova, L.R.; Baranova, G.B.; Baranova, E.N.; Khaliluev, M.R. Comparative anatomical and morphological studies of the epidermal and cortical parenchyma hypocotyl cells of two tomato genotypes (Solanum lycopersicum L.) under sodium chloride stress in vitro. Sel'skokhozyaistvennaya Biol. 2016, 51, 318-326. [CrossRef] 